\title{
Leaf area and intermittent misting on hop plants propagation by stem cuttings
}

\section{Área foliar y nebulización intermitente en la propagación de lúpulo por estacas de tallo}

ERIK NUNES GOMES 1,3

MARÍLIA PEREIRA MACHADO²

JOSÉ MIOLA²

CÍCERO DESCHAMPS ${ }^{2}$

Hop plants (cv. Chinook) stock plants grown in field conditions at Southern Brazil.

Photo: M.P. Machado

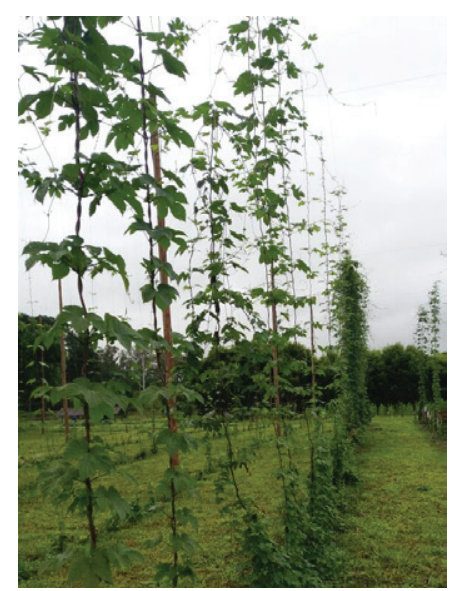

\begin{abstract}
Hop (Humulus lupulus L.) is a plant with economic importance due to its use in the brewing industry. The cones produced by the species contain the main substances responsible for the beer's bitterness and aroma. Hop plants cultivation in Brazil is still incipient and information on efficient methods for its propagation in this context are scarce. The objective of the present study was to evaluate the effect of different leaf areas (two whole leaves, two leaves in half, one whole leaf, one leaf in half and without leaves) in herbaceous stem cuttings planted in environments with and without intermittent misting. The experiment was conducted in

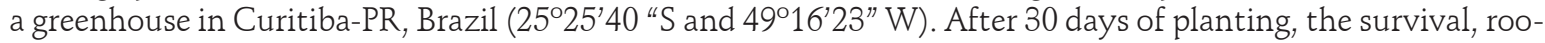
ting, sprouting and leaf retention percentages, roots number, average roots length and roots and sprouts dry mass were evaluated. Cuttings with one or two whole leaves and two leaves in half in the misting environment showed the highest rooting percentages (between 90.0 and $97.5 \%$ ). In the without misting environment, the highest values were observed in cuttings with one or two leaves in half and one whole leaf (between 62.5 and $72.5 \%$ ). Leafless cuttings had low survival percentages $(2.5 \%$ in both environments). Under intermittent misting conditions it is recommended to prepare stem cuttings with one or two whole leaves and, in the absence of control over the environment humidity, cuttings with one whole leaf are recommended.
\end{abstract}

\footnotetext{
Additional key words: Humulus lupulus, Chinook, asexual reproduction,

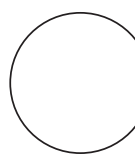
rooting, growth environments, transpiration.

Department of Plant Biology and Plant Pathology at Rutgers, The State University of New Jersey, New Brunswick-NJ (USA). ORCID Gomes, E.N.: 0000-0002-7999-070X

2 Departamento de Fitotecnia e Fitossanitarismo, Setor de Ciências Agrárias, Universidade Federal do Paraná, Curitiba-PR (Brazil). ORCID Machado, M.P.: 0000-0002-3209-4780; ORCID Miola, J.: 0000-0003-4264-2792; ORCID Deschamps, C.: 0000-0003-0786-0532

3 Corresponding author.e93gomes@gmail.com
} 


\section{RESUMEN}

Lúpulo (Humulus lupulus L.) es una planta con una economía importante debido a su uso en la industria cervecera. Los conos producidos por esta especie contienen las principales sustancias responsables de la amargura y el aroma de la cerveza. El cultivo de plantas de lúpulo en Brasil es aún incipiente en la información y los métodos eficientes para su propagación son escasos en este contexto. El objetivo del presente estudio fue evaluar el efecto de las diferentes áreas de hoja (dos hojas enteras, dos hojas a la mitad, una hoja entera, una hoja a la mitad y estacas sin hojas) en estacas herbáceas plantadas en ambientes con y sin nebulización intermitente. El experimento fue conducido en

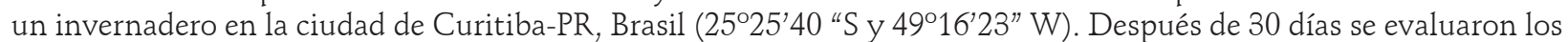
porcentajes de supervivencia, enraizamiento, brotación y retención de hojas, número de raíces, longitud promedio de raíces y masa seca de raíces y brotes. Las estacas con una o dos hojas enteras y dos hojas a la mitad, bajo nebulización, mostraron los porcentajes de enraizamiento más altos (entre 90 y 97,5\%). En el ambiente sin niebla, los valores más altos se observaron en los esquejes con una o dos hojas por la mitad y una hoja entera (entre 62,5 y 72,5\%). Las estacas sin hojas tuvieron bajos porcentajes de supervivencia (2,5\% en ambos ambientes). Bajo condiciones de neblina intermitente, se recomienda preparar esquejes de tallo con una o dos hojas enteras y, sin nebulización, se recomiendan esquejes con una hoja entera.

Palabras clave: Humulus lupulus, Chinook, reproducción asexual, enraizamiento, ambientes de crecimiento, transpiración.

Received for publication: 10-01-2018 Accepted for publicacation: 30-05-2018

INTRODUCTION

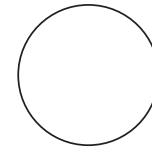

Humulus lupulus L., the hop plant, is a perennial, herbaceous, dioecious and rhizomatous species, belonging to the Canabaceae family. Its development is characterized by emitting new shoots from rhizomes in the Spring and by reaching from 6 to $9 \mathrm{~m}$ in height, needing support in order to sustain its growth. It blooms in late summer, matures the flowers and begins the senescence in the autumn, when it loses all the aerial parts (Koetter and Biendl, 2010; Almaguer et al., 2014). The female flowers commonly called hops, are located in strobiles with rounded shape (cones). These cones hold glandular trichomes that store the major substances of commercial importance in the species (Almaguer et al., 2014). Around the world, the brewing industry uses $H$. lupulus L. flowers as an essential component in the brewing process, as they are responsible for their bitterness and aroma (Silva and Faria, 2008; Nance and Setzer, 2011).

Because it is a dioecious plant, H. lupulus L. is highly heterozygous, so the populations obtained by seeds are strongly variable, losing the characteristics that provide the commercial value from the cultivar that originated them. Therefore, for commercial purposes, $H$. lupulus $\mathrm{L}$. is propagated vegetatively, both from rhizomes and herbaceous cuttings
(DeNoma, 2000), in order to maintain the characteristics of the cultivars.

Among the factors that influence the adventitious rooting of stem cuttings, the presence of leaves is one of the most important because it has a promoter effect at the beginning of root formation and roots development (Solis et al., 2017). In H. lupulus L., the success of leafy stem cuttings in rooting is probably associated with their ability to accumulate carbohydrates during the rooting period through photosynthesis (Howard, 1965). Rooting of stem cuttings is also influenced by endogenous auxin produced in the leaves and buds (Bona and Biasi, 2010; Dias et al., 2015).

In addition, the rooting of cuttings depends on environmental factors to maintain the water balance in plant tissues. Intermitent misting is a widely used tool in vegetative propagation because it reduces the air temperature and the rate of transpiration by maintainig a film of water over the cuttings (Sousa et al., 2013). However, where the structure necessary to provide the adequate environmental conditions for the cuttings is not available, alternatives must be indicated. 
The objective of the present study was to evaluate the rooting of $H$. lupulus L. cv. Chinook stem cuttings with different leaf areas in environments with and without intermittent misting.

\section{MATERIAL AND METHODS}

The experiment was conducted in a greenhouse at the Department of Phytotechnology and Phytosanitaryism of the Agrarian Sciences Sector of the Federal University of Parana, in the city of Curitiba-PR, Brazil ( $25^{\circ} 25^{\prime} 40$ "S and $\left.49^{\circ} 16^{\prime} 23^{\prime \prime} \mathrm{W}\right)$.

The Humulus lupulus stem cuttings were collected from the apical segment of 10 two years old Chinook cultivar stock plants. The stock plants were cultivated in pots under greenhouse conditions at the Center of Experimental Stations of Canguiri (CEEx, Federal University of Parana), municipality of Pinhais-PR, Brazil (25'23'30" S and 49 $07^{\prime} 30^{\prime \prime} \mathrm{W}, 930 \mathrm{~m}$ a.s.l.). The plant material (branches with leaves) was collected in May 2017 in the morning period, moistened and placed in a polystyrene box for transportation to the greenhouse where the cuttings were made.

The herbaceous stem cuttings were made with $0.5 \pm 0.1 \mathrm{~cm}$ diameter, $5 \pm 2 \mathrm{~cm}$ in length, with a diagonal (bevel) cut at the base and a straight cut at the apex. The cuttings were prepared with different leaf areas corresponding to the treatments: two whole leaves in the apical region, two leaves reduced to half of its original area, one whole leaf, one leaf reduced to half of its original area, and leafless cuttings. The stem cuttings have not undergone any type of sanitary treatment or plant growth regulators application. After cuttings preparation, they were immediately planted in polystyrene trays containing 128 cells $\left(40 \mathrm{~cm}^{3}\right.$ per cell) filled with Tropstrato $\mathrm{HT}^{\oplus}$ commercial substrate.

The cuttings were conducted under two different environments in the same greenhouse: (1) intermittent misting chamber ( $5 \mathrm{~s}$ every $30 \mathrm{~min}$ ) and (2) no intermittent misting. In the without misting environment, the cuttings were irrigated manually with 700 $\mathrm{mL}$ of water per tray, twice a week.

The experimental design was completely randomized in a $5 \times 2$ factorial arrangement (five leaf areas and two rooting environments). The experiment had four replications and the experimental units consisted of 10 cuttings, totaling 400 cuttings in the experiment.
After $30 \mathrm{~d}$ of planting, the survival, rooting, sprouting and leaf retention percentages, roots number, average roots length and roots and sprouts dry mass were evaluated. Data were submitted to variance homogeneity analysis by the Bartlett's test, ANOVA variance analysis and, when significant, the means were compared by Tukey's test at $5 \%$ probability. The Assistat statistical software (Silva and Azevedo, 2016) was used to perform the analyses.

\section{RESULTS AND DISCUSSION}

According to variance analysis, there was an interaction effect $(P \leq 0.01)$ for survival, rooting and sprouting percentages. Considering the factors alone, the leaf area factor was significant for leaf retention percentage, roots number, average roots length and roots and sprouts dry mass. The misting factor influenced the leaf retention percentage, roots number, average roots length (Tab. 1 and 2).

The cuttings survival and rooting ranged from 97.5 to $2.5 \%$. The sprouting percentage varied from 85 to $2.5 \%$. Stem cuttings with two whole leaves, two leaves in half and one whole leaf did not differ in the environment with intermittent misting. In the non-misting environment, cuttings with two leaves in half and one whole leaf were superior to those with two whole leaves for survival and rooting variables (Tab. 1).

Stem cuttings with two whole leaves without intermittent misting had their performance reduced, probably due to excessive transpiration, which caused its death. The loss of water due to transpiration and low roots quality are among the main causes of death in herbaceous cuttings. Loss of water through the leaves can lead to a state of desiccation, impacting their survival (Pacheco and Franco, 2008). The control of transpiration provided by misting may explain the best performance of cuttings with two whole leaves in this environment.

Humidity is one of the key external factors to stimulate the rooting of stem cuttings (Amaral et al., 2012). Thus, control over humidity in the environment may result in improved survival and rooting (Braun et al., 2010). The use of intermittent misting has been recommended to reduce air temperature and transpiration rate, since it allows the maintenance of water film on the cuttings (Sousa et al., 2013). The results of hop cuttings observed in present study are similar 
Table 1. Stem cuttings survival, rooting and sprouting percentages in Humulus lupulus cv. Chinook with different leaf areas and presence/absence of intermittent misting. Curitiba-PR, Brazil (2017).

\begin{tabular}{|l|c|c|c|c|c|c|}
\hline \multirow{2}{*}{\begin{tabular}{c}
\multirow{2}{*}{ Leaf } \\
\cline { 2 - 7 }
\end{tabular}} & \multicolumn{4}{|c|}{ Survival (\%) } & \multicolumn{2}{c|}{ Rooting (\%) } \\
\cline { 2 - 7 } & Misting & Non-misting & Misting & Non-misting & Misting & Non-misting \\
\cline { 2 - 7 } & $92.5 \mathrm{aA}$ & $52.5 \mathrm{bB}$ & $92.5 \mathrm{aA}$ & $45.0 \mathrm{bB}$ & $85.0 \mathrm{aA}$ & $50.0 \mathrm{aB}$ \\
\hline 2 half leaves & $90.0 \mathrm{aA}$ & $72.5 \mathrm{aB}$ & $90.0 \mathrm{aA}$ & $72.5 \mathrm{aB}$ & $85.0 \mathrm{aA}$ & $67.5 \mathrm{aB}$ \\
\hline 1 whole leaf & $97.5 \mathrm{aA}$ & $70.0 \mathrm{aB}$ & $97.5 \mathrm{aA}$ & $70.0 \mathrm{aB}$ & $82.5 \mathrm{aA}$ & $70.0 \mathrm{aA}$ \\
\hline 1 half leaf & $75.0 \mathrm{bA}$ & $62.5 \mathrm{abB}$ & $75.0 \mathrm{bA}$ & $62.5 \mathrm{aB}$ & $52.5 \mathrm{bA}$ & $62.5 \mathrm{aA}$ \\
\hline Leafless cutting & $2.5 \mathrm{cA}$ & $2.5 \mathrm{cA}$ & $2.5 \mathrm{cA}$ & $2.5 \mathrm{cA}$ & $2.5 \mathrm{cA}$ & $2.5 \mathrm{bA}$ \\
\hline CV (\%) & 11.16 & 10.58 & & 19.58 & \\
\hline
\end{tabular}

Means followed by the same lowercase letter in the columns and upper case in the rows do not differ from each other by the Tukey's test $(P \leq 0.05)$. CV: coefficient of variation.

Table 2. Leaf maintenance, roots number, average roots length, roots dry mass and sprouts dry mass in Humulus lupulus cv. Chinook herbaceous stem cuttings with different leaf areas and in the presence/absence of intermittent misting in rooting environments. Curitiba-PR, Brazil (2017).

\begin{tabular}{|c|c|c|c|c|c|c|c|}
\hline \multirow{6}{*}{ 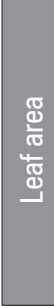 } & Variable & 2 whole leaves & 2 half leaves & 1 whole leaf & 1 half leaf & Leafless cuttings & CV $(\%)$ \\
\hline & Leaf maintenance (\%) & $67,5 a b$ & $75,0 \mathrm{a}$ & $71,25 a b$ & $55,0 \mathrm{~b}$ & - & 20.66 \\
\hline & Roots number & $21,1 \mathrm{a}$ & $17,67 a b$ & $17,04 a b$ & $14,96 \mathrm{~b}$ & $0,63 \mathrm{c}$ & 26.21 \\
\hline & Roots length $(\mathrm{cm})$ & $5,77 a$ & $5,02 \mathrm{a}$ & $4,81 \mathrm{a}$ & $5,06 \mathrm{a}$ & $0,31 \mathrm{~b}$ & 28.44 \\
\hline & Roots dry mass (mg) & $39,60 \mathrm{a}$ & $32,67 a b$ & $22,53 a b$ & 16,40 bc & $2,88 \mathrm{c}$ & 54.69 \\
\hline & Sprouts dry mass (mg) & $41,39 \mathrm{a}$ & $30,34 \mathrm{a}$ & 34,63 a & $38,02 \mathrm{a}$ & $3,00 \mathrm{~b}$ & 51.08 \\
\hline \multirow{6}{*}{ 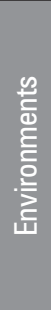 } & Variable & \multicolumn{2}{|c|}{ Misting } & & \multicolumn{2}{|c|}{ Non-misting } & \\
\hline & Leaf maintenance (\%) & \multicolumn{2}{|c|}{$81,25 \mathrm{a}$} & & \multicolumn{2}{|c|}{$53,12 b$} & 20.66 \\
\hline & Roots number & \multicolumn{2}{|c|}{$16,21 \mathrm{a}$} & & \multicolumn{2}{|c|}{$12,35 b$} & 26.21 \\
\hline & Roots length $(\mathrm{cm})$ & \multicolumn{2}{|c|}{4,58 a } & & \multicolumn{2}{|c|}{$3,80 \mathrm{~b}$} & 28.44 \\
\hline & Roots dry mass $(\mathrm{mg})^{\text {ns }}$ & \multicolumn{2}{|c|}{22,84} & & \multicolumn{2}{|c|}{22,79} & 54.69 \\
\hline & Sprouts dry mass $(\mathrm{mg})^{\mathrm{ns}}$ & \multicolumn{2}{|c|}{25,19} & & \multicolumn{2}{|c|}{33,77} & 51.08 \\
\hline
\end{tabular}

Means followed by different letters in the rows differ by the Tukey's test $(P \leq 0.05)$. ns: non-significant. CV: coefficient of variation.

to those reported for herbaceous Cuphea calophylla stem cuttings, where misting allowed the advantageous effect of leaves for rooting to not be overcome by the adverse effects related to the excess of transpiration (Lusa and Biasi, 2011).

In conditions where the environment humidity control is not possible, however, the reduction of leaf area in hops stem cuttings may be important. The technique of leaf area reduction in cuttings has as main objective to avoid the "umbrella" effect, which may impair irrigation efficiency, and to avoid excessive transpiration (Santana et al., 2010; Correia et al., 2015). In Plukenetia polyadenia stem cuttings, the leaf area reduction by $50 \%$ allowed to reach the best balance between the transpiration disadvantages and the photosynthesis advantages, the authors emphasize, however, that the optimal leaf area for rooting is variable according to different species (Solis et al., 2017). According to the present study, for hop cuttings, the optimum leaf area is also variable according to the rooting environment.

In the environment without misting, the use of cuttings with one whole leaf had the same effect of the use of two leaves in half, both being superior to the cuttings with two whole leaves. This response has important agronomic implications, since the use of 
an entire leaf in detriment of two leaves in half can be technically advantageous by the reduction of the time and labor in cuttings production (Santana et al., 2010). In addition, the preparation of cuttings with whole leaves reduces the risk of contamination by microorganisms due to the absence of lesions (Dias et al., 2015).

Regardless of the environment, the leafless cuttings had the lowest values of survival and rooting. Early root formation is hormonally controlled and the reserves present in the cuttings and photoassimilates produced in the leaves influence its development (Solis et al., 2017). Root initiation and development are dependent on auxins, carbohydrates, nitrogen compounds and rooting cofactors that are supplied by the leaves and accumulate cutting base, in this sense, as a general rule, the presence of leaves is important when used herbaceous or semi-hardwood cuttings for plant propagation (Bona and Biasi, 2010). In a previous experiment with hop herbaceous cuttings, the presence of leaves was associated with the ability to accumulate carbohydrates and to stimulate rooting especially in conditions of intermittent misting and high light intensity (Howard, 1965).

In the present study the environment with misting, in general, promoted higher values of survival, sprouting and rooting, except in leafless cuttings. Cuttings with one leaf in half, in the misting environment, presented values markedly inferior to the others, except the treatment composed by leafless cuttings (Tab. 1). Without misting, cuttings with a leaf in half showed greater rooting percentages than cuttings with two whole leaves, demonstrating that in this environment the main limiting factor was the transpiration and not the reserves supplied to the cuttings base.

For the sprouting percentage, in the without misting environment, all types of cuttings were superior to the leafless cuttings. Under misting, cuttings with two whole leaves, two leaves in half and $\mathrm{c}$ with one whole leaf were superior to those with one leaf in half, which, in turn, was superior to the leafless cuttings. The inferiority of sprouting percentage and sprouts dry mass in leafless cuttings (Tab. 2) is related, similarly to rooting, to leaves function in photosynthesis and availability of carbohydrates to the cuttings (Solis et al., 2017).

Leaf retention in cuttings with two leaves in half was superior to cuttings with one leaf in half. The other treatments did not differ from each other. For the roots number, cuttings with two whole leaves presented better performance than those with one leaf in half. All the cuttings with the maintenance of some fraction of the leaf area showed a greater number of roots compared to the leafless cuttings. Roots length was also lower in the leafless cuttings and there was no difference between the other treatments, similar to that observed for sprouts dry mass. For the roots dry mass, leafless cuttings and cuttings with one leaf in half were inferior to cuttings with two whole leaves (Tab. 2).

In eucalyptus mini-cuttings, similar to the observed in hop plant cuttings, there is a positive relation between leaf area and rizogenic capacity, including rooting rate, root number and root biomass (Correia et al., 2015). In the case of medicinal and aromatic species such as Cuphea calophylla (Lusa and Biasi, 2011), Pogostemon cablin (Garbuio et al., 2007), Lavandula dentata (Bona and Biasi, 2010) and Plukenetia polyadenia (Solis et al., 2017), among others, the presence of leaves on cuttings was also positively related to rooting and root system vigor.

Regarding the rooting environment, the presence of misting promoted higher values of leaf retention, number of roots and average roots length (Tab. 2). In addition to higher mortality, the worst rooting and roots vigor in stem cuttings with damage to water relations may also be related to the lower displacement of auxins due to low water content (Pizzatto et al., 2011).

\section{CONCLUSION}

Humulus lupulus cv. Chinook propagation by stem cutting is feasible, reaching rooting percentages up to $97.5 \%$ without plant growth regulators use. Leafless stem cuttings are not recommended for hop plant propagation. Under intermittent misting conditions it is recommended the use of cuttings with one or two whole leaves and, in the absence of control over the environment humidity, cuttings with one whole leaf are recommended. The use of intermittent misting in the rooting environment allows higher percentages of survival, rooting, sprouting and greater vigor of the root system in hop plant herbaceous stem cuttings. Further studies are recommended to evaluate the adaptation of plants propagated by stem cuttings under Brazilian cultivation conditions. 


\section{ACKNOWLEDGMENTS}

The authors would like to acknowledge the Brazilian Federal Agency for Support and Evaluation of Graduate Education (CAPES) by sponsorship of the research and doctorate scholarship granted to the first author.

Conflict of interests: the manuscript was prepared and reviewed with the participation of the authors, who declare that there exists no conflict of interest that puts in risk the validity of the presented results.

\section{BIBLIOGRAPHIC REFERENCES}

Almaguer, C., C. Schonberger, M. Gastl, E.K. Arendt, and T. Becker. 2014. Humulus lupulus - a story that begs to be told. A review. J. Brew. Distilling. 120(4), 289-314. Doi: $10.1002 /$ jib.160

Amaral, G.C., L.P.D.S. Brito, R.C. Avelino, J.V.D. Silva Júnior, M.Z. Beckmann-Cavalcante, and I.H.L. Cavalcante. 2012. Produção de mudas de Duranta repens L. pelo processo de estaquia. Rev. Cienc. Agr. 35(1), 134-142.

Bona, C.M.D. and L.A. Biasi. 2010. Influence of leaf retention on cutting propagation of Lavandula dentata L. Rev. Ceres. 57(4), 526-529. Doi: 10.1590/ S0034-737X2010000400014

Braun, H., P.C. Cavatte, J.A. Teixeira do Amaral, J.F. Teixeira do Amaral, and E.F. Reis. 2010. Produção de mudas de tomateiro por estaquia: efeito do substrato e comprimento de estacas. Idesia 28(1), 9-15. Doi: 10.4067/ S0718-34292010000100002

Correia, A.C.G., A. Xavier, P.C. Dias, M. Titon, and R.C. Santana. 2015. Redução foliar em miniestacas e microestacas de clones híbridos de Eucalyptus globulus. Rev. Árvore 39(2), 295-304. Doi: 10.1590/0100-67622015000200009

DeNoma, J.S. 2000. Humulus genetic resources: Hop. USDA ARS National Clonal Germplasm repository. USDA ARS National Clonal Germplasm Repository. In: https://www.ars.usda.gov/pacific-west-area/corvallis-or/national-clonal-germplasm-repository/docs/ ncgr-corvallis-humulus-germplasm; consulted: July, 2017.

Dias, P.C., A. Xavier, L. Silva de Oliveira, A.C. Guieiro Correia, and G.A. Barbosa. 2015. Tipo de miniestaca e de substrato na propagação vegetativa de angico-vermelho (Anadenanthera macrocarpa (Benth.) Brenan). Cienc. Florestal 25(4), 909-919. Doi: 10.5902/1980509820593

Garbuio, C., L.A. Biasi, A.P.D.J. Kowalski, D. Signor, E.M. Machado, and C. Deschamps. 2007. Propagação por estaquia em patchouli com diferentes números de folhas e tipos de estacas. Scientia Agr. 8(4), 435-438. Doi: $10.5380 /$ rsa.v8i4.9893

Howard, B.H. 1965. Regeneration of the hop plant (Humulus lupulus L.) from softwood cuttings. I. the cutting and its rooting environment. J. Hortic. Sci. 40(1), 181191. Doi: 10.1080/00221589.1965.11514132.

Koetter, U. and M. Biendl. 2010. Hops (Humulus lupulus): A review of its historic and medicinal uses. J. Am. Bot. Council 87(1), 44-57.

Lusa, M.G. and L.A. Biasi. 2011. Estaquia de Cuphea calophylla subsp. mesostemon (Koehne) Lourteig (Lythraceae). Rev. Bras. Pl. Med. 13(1), 52-57. Doi: 10.1590/ S1516-05722011000100008

Nance, M.R. and W.N. Setzer. 2011. Volatile components of aroma hops (Humulus lupulus L.) commonly used in beer brewing. J. Brew. Distilling 2(2), 16-22.

Pacheco, J.P. and E.T.H. Franco. 2008. Substratos e estacas com e sem folhas no enraizamento de Luehea divaricata Mart. Cienc. Rural 38(7), 1900-1906. Doi: 10.1590/ S0103-84782008000700015

Pizzatto, M., A. Wagner Júnior, D. Luckmann, K. Pirola, D.A. Cassol, and S.M. Mazaro. 2011. Influência do uso de AIB, época de coleta e tamanho de estaca na propagação vegetativa de hibisco por estaquia. Rev. Ceres 58(4), 487-492. Doi: 10.1590/ S0103-84782008000700015

Santana, R.C., T.R. Dutra, J.P. Carvalho Neto, G.S. Nogueira, P.H. Grazziotti, and N.F.D Barros Filho. 2010. Influence of leaf area reduction on clonal production of eucalyptus seedlings. Cerne 16(3), 251-257. Doi: 10.1590/S0104-77602010000300001

Silva, F.D.A.S. and C.A.V Azevedo. 2016. Comparison of means of agricultural experimentation data through different tests using the software Assistat. Afr. J. Agric. Res. 11(1), 3527-3531. Doi: 10.5897/AJAR2016.11522

Silva, P.H.A. and F.C. Faria. 2008. Avaliação da intensidade de amargor e do seu princípio ativo em cervejas de diferentes características e marcas comerciais. Ciênc. Tecnol. Aliment. 28(4), 902-906. Doi: 10.1590/ S0101-20612008000400021

Solis, R., M. Pezo, G. Diaz, L. Arévalo, and D. Cachique. 2017. Vegetative propagation of Plukenetia polyadenia by cuttings: effects of leaf area and indole-3-butyric acid concentration. Braz. J. Biol. 77(3), 580-584. 10.1590/1519-6984.20415

Sousa, C.M., R.N. Busquet, M.A.D.S. Vasconcellos, and R.M. Miranda. 2013. Effects of auxin and misting on the rooting of herbaceous and hardwood cuttings from the fig tree. Rev. Cienc. Agron. 44(2), 334-338. Doi: 10.1590/S1806-66902013000200016 